\title{
Diversity and fruiting pattern of macrofungi associated with chestnut (Castanea sativa) in the Trás-os-Montes region (Northeast Portugal)
}

\author{
Paula BAPTISTA ${ }^{a, *}$, Anabela MARTINS ${ }^{a}$, Rui Manuel TAVARES $^{b}$, Teresa LINO-NETO $^{b}$ \\ ${ }^{a}$ CIMO/Escola Superior Agrária do Instituto Politécnico de Bragança, Quinta de Sta Apolónia, Campus de Santa Apolonia, \\ Apartado 1172, 5301-855 Bragança, Portugal \\ ${ }^{\mathrm{b} C e n t e r}$ for Biodiversity, Functional \& Integrative Genomics (BioFIG), Departamento de Biologia, Universidade do Minho, \\ Campus de Gualtar, 4710-057 Braga, Portugal
}

\section{A R T I C L E I N F O}

Article history:

Received 24 January 2009

Revision received 17 May 2009

Accepted 15 June 2009

Available online 21 July 2009

Corresponding editor: Jacob

Heilmann-Clausen

\section{Keywords:}

Castanea sativa Mill

Fruiting phenology

Macrofungal occurrence

Macrofungal species diversity

\begin{abstract}
A B S T R A C T
The chestnut (Castanea sativa) agro-ecosystem is of great social, economic and landscape importance in NE Portugal. There are multiple resources associated with this crop, among them fruit and wood production and mushroom harvesting. However, information about the diversity and ecology of macrofungi is very scarce. In this context, the aim of this study was to assess the macrofungal diversity associated with chestnut trees over $4 \mathrm{y}$. Carpophore surveys were conducted in a non-tilled C. sativa orchard located in Bragança, Portugal, from Sep. 2002 to Dec. 2005. A total of 2677 carpophores belonging to 73 species across 16 families and 23 genera were recorded. Of the total number of macrofungal species listed, $82 \%$ were ectomycorrhizal (EM) species. The genera with the greatest species richness were Russula, Inocybe and Lactarius, which accounted for $38.4 \%$ of all species collected. The most abundant species were Laccaria laccata, Hebeloma crustuliniforme and Inocybe geophylla, which produced around $35 \%$ of all carpophores. The cumulative number of species over the four successive years revealed that $80.5 \%$ of macrofungal species that potentially exist in the study area were surveyed. Species richness and carpophore abundance fluctuated across years, which could have been related to weather conditions, especially to rainfall. Fructification occurred in two distinct seasons a year, autumn and spring, the first one being the most important in terms of number of species and carpophores. These data could be an important contribution toward the development of sustainable management practices for chestnut agro-ecosystem conservation.
\end{abstract}

(c) 2009 Elsevier Ltd and The British Mycological Society. All rights reserved.

\section{Introduction}

Portugal has the largest area of chestnut trees (Castanea sativa) in the European Union (Anonymous 2006). The widespread range of chestnut trees in this country is mainly related to the cultivated varieties in grafted orchards for fruit production.
Forest that produces high-quality timber is scarce and represents less than $10 \%$ of the total Portuguese chestnut area (Anonymous 2007). Although chestnut is cultivated all over Portugal, it is in the coldest areas in the north (The Trás-osMontes region) that it is most important. In 2006, approximately 85 \% (25644 ha) of the 30097 ha of Portuguese chestnut

\footnotetext{
* Corresponding author. Tel.: +351 273303332; fax: +351 273325405.

E-mail address: pbaptista@ipb.pt (P. Baptista).

1754-5048/\$ - see front matter ( 2009 Elsevier Ltd and The British Mycological Society. All rights reserved. doi:10.1016/j.funeco.2009.06.002
} 
tree area was in the Trás-os-Montes region (Anonymous 2007). The European chestnut tree, as a nut and timber producer, plays an important role in the economy of the Trás-os-Montes region. Chestnut wood is one of the preferred choices in making high quality furniture. The nuts constitute the most important export product of the Portuguese fruit sector (Anonymous 2007). Additionally, over the last decade another important income associated with these trees has emerged the collection and commercialization of wild edible mushrooms growing in chestnut stands. Despite the poor knowledge of their biodiversity, ecology or sustainable management in those regions, mushroom harvesting is increasing, mainly due to their economic importance to local populations. Considering the species most frequently commercialized in the region (Amanita caesarea, Boletus edulis, B. aereus, Cantharellus cibarius, Hydnum rufescens and Calocybe gambosa), small-scale studies indicated that the average total income can reach $134 € \mathrm{ha}^{-1} \mathrm{y}^{-1}$ (Baptista et al. 2007).

C. sativa establishes ectomycorrhizal (EM) associations with a number of fungi (Harley \& Harley 1987). Positive effects for the chestnut plant were verified after mycorrhization with the EM fungi Pisolithus tinctorius (Martins 1997; Martins et al. 1997), Laccaria laccata, Hebeloma crustuliniforme, H. sinapizans and Paxillus involutus (Branzanti et al. 1999). These associations promote increased availability of mineral nutrients, growth and productivity of chestnut plants, and exert a protective effect against root pathogens (Martins 1997, 2004; Martins et al. 1997; Branzanti et al. 1999). Several cultivation practices have been linked to the recent decline of chestnut tree, for example, soil tillage contributes to the appearance of diseases such as chestnut ink disease, caused by Phytophthora spp., and chestnut blight (Cypthonectria parasitica) (Martins et al. 2007). Since several EM fungi seem to exert a protective effect against root pathogens (Branzanti et al. 1999; Martins 2004), knowledge of the EM fungal diversity associated with chestnut trees at a local scale will provide important information for management decisions in the ecosystem. In Portugal, and specifically in the Trás-osMontes region, lack of information on the diversity, abundance and fruiting pattern of EM fungi associated with this ecosystem, hinders development of new management practices.

Despite the symbiotic association between chestnut roots and some soil fungi having been previously described, knowledge about diversity of EM fungi, their ecology, or sustainable management in chestnut stands is scarce, only short-term monitoring having been performed. To our knowledge, there have been only two long-term studies in chestnut coppices, comprising a period of 18-y in Greece (Diamandis \& Perlerou 2001) and 4-y in central-southern Tuscany (Italy) (Laganà et al. 2002a). Another study was performed during only one fruiting season in Romania (Chira \& Chira 2003). The identification of fungi in these studies was entirely based on their sexual reproductive structures, visible to the naked eye above ground. Surveys of EM fungal carpophores does not adequately reflect the below ground EM fungal diversity because some species lack carpophores or have a sporulating strategy that is disproportional to their underground abundance (Gardes \& Bruns 1996a; Horton \& Bruns 2001). Despite their limitation, fruitbody surveys are considered the primary basis for documenting fungal diversity in a stand (Smith et al. 2002) since they can be easily identified at the species level (Richard et al. 2004). In addition, fruiting patterns, which allow for a comparison of current and historic carpophore data, constitute a valuable tool for management and conservation strategies (Molina et al. 2001; Richard et al. 2004). Carpophore surveys can also provide insight into the characteristics of fungi and may explain their habitat segregation (Matsuda \& Hijii 1998).

The present study aims to provide information on the macrofungal community (EM and non-EM fungi) associated with sweet chestnut tree in the Trás-os-Montes region (Northeast Portugal). A systematic survey was done over four consecutive years, from 2002 to 2005, in a chestnut orchard and the diversity (species richness and abundance), frequency of occurrence of macrofungal species and their fruiting phenology were studied. The changes that occurred over time in the macrofungal community was analyzed and related with climatic conditions (temperature and rainfall).

\section{Methods}

\section{Study area}

The study was conducted in a 100+-year-old non-tilled C. sativa orchard (about 1.5 ha of surface), located in Oleiros Bragança (NE Portugal) $\left(41^{\circ} 51^{\prime} 15^{\prime \prime} \mathrm{N}, 6^{\circ} 49^{\prime} 20^{\prime \prime} \mathrm{W}, 915 \mathrm{~m}\right.$ a.s.l.) in the Natural Park of Montesinho (Fig 1). The orchard encompassed a range of shrubs frequently associated with chestnut trees, dominated by Genista sp. and Ulex sp. The only anthropogenic disturbance during the research period was due to chestnut picking each Nov. For facilitating this process, the current practice performed by locals is to remove soil debris with forks. The prevailing climate of the area is sub-continental with long cold winters and short, hot and dry summers. The average annual rainfall ranges from 1000 to $1200 \mathrm{~mm}$, about $90 \%$ occurring between Oct. and Apr. The annual mean air temperature was $10-14{ }^{\circ} \mathrm{C}$, with temperatures ranging from $0{ }^{\circ} \mathrm{C}$ (mean Jan. minima) to $28^{\circ} \mathrm{C}$ (mean Jul. maxima) (Agroconsultores \& Coba 1991). The predominant soils are chromic dystric cambisols (according to FAO-Unesco-Isric 1988) derived from migmatitic and gneissic parent materials, and cover gentle to very gentle slopes (Agroconsultores \& Coba 1991). At a depth of $20 \mathrm{~cm}$, the soil had a pH value of 5.3 and an organic matter content of $3.3 \%$. Total nitrogen $(\mathrm{N})$ was $0.1 \%$ while phosphorus $\left(\mathrm{P}_{2} \mathrm{O}_{5}\right)$ and potassium $\left(\mathrm{K}_{2} \mathrm{O}\right)$ contents were $8 \mathrm{ppm}$ and $320 \mathrm{ppm}$, respectively.

During the surveyed period, meteorological data were collected at a weather station $5 \mathrm{~km}$ from the studied area. Cumulative rainfall and average daily temperatures (mean, maximum and minimum) from $3,10,20$ or $30 \mathrm{~d}$ before the sampling date were determined.

\section{Fungal survey}

The study was conducted in five permanent non-contiguous plots, $100 \mathrm{~m}^{2}$ each, marked off by visible posts at each corner to facilitate sampling. The plots were chosen to have similar ecological conditions (exposition, slope and type of vegetation). From Sep. 2002 to Dec. 2005, all macrofungal carpophores were collected weekly (during autumn and spring) or biweekly 

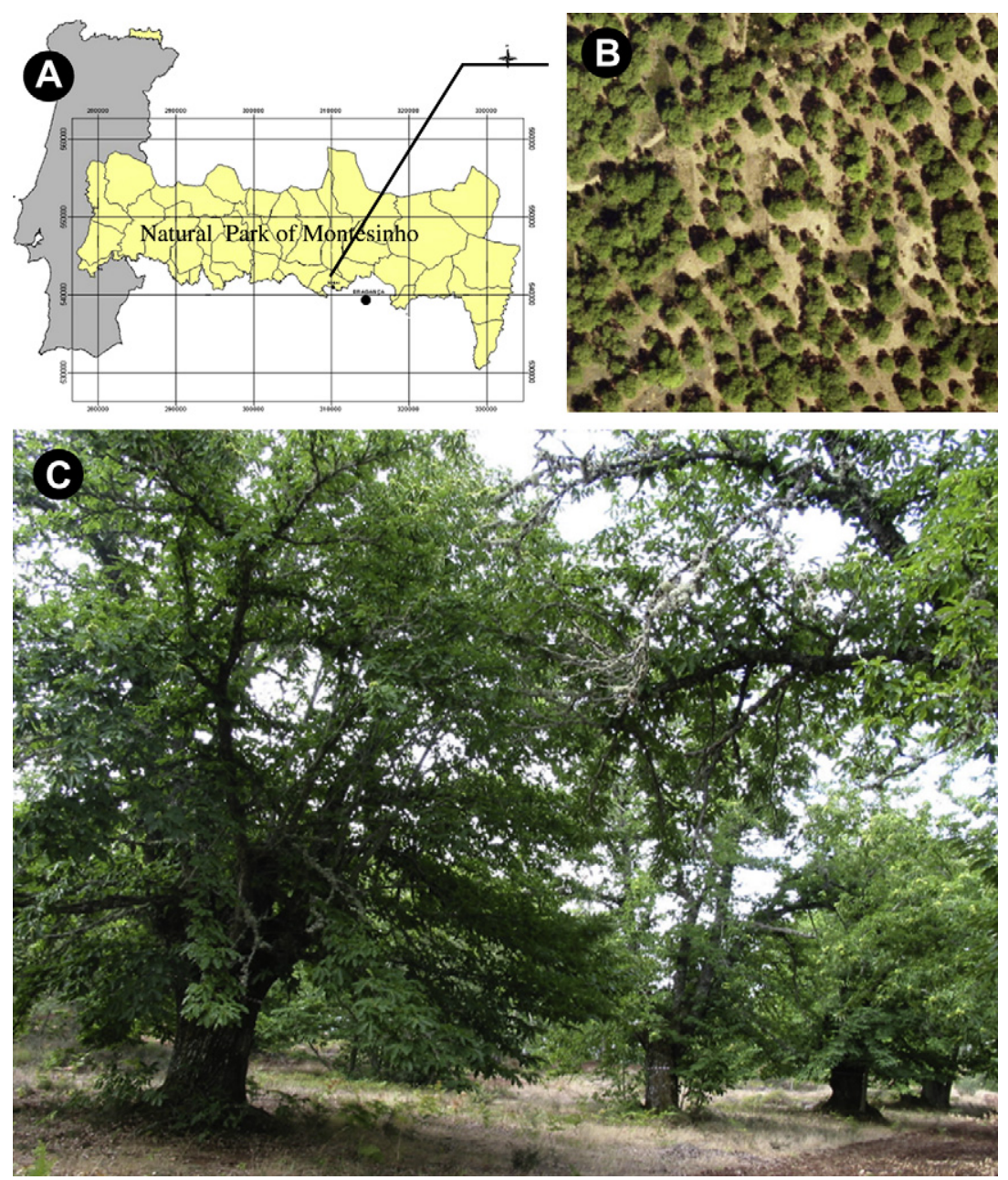

Fig 1 - Chestnut orchard study site. Geographical location - Natural Park of Montesinho, Northeast Portugal (A), aerial view (B) and typical plot (C).

(in winter and summer periods) within each plot. Carpophore surveys were limited to epigeous macromycetes of soil and wood-inhabiting fungi that were visible to the naked eye (greater than $1 \mathrm{~mm}$ in size). No assessments were made during Jan., Feb., Mar., and Aug., since during these months very few macrofungi produce carpophores in Bragança.

\section{Fungal identification and processing}

Carpophores were counted and identified in the laboratory. Carpophores were identified to genus and in most cases to species using morphological features and appropriate keys and monographs including Marchand (1971-1986), Moser (1983), Breitenbach \& Kränzlin (1984-2000), Alessio (1985), Bon (1988), Noordeloos (1988-2001), Candusso \& Lanzoni (1990), Bas et al. (1990-2001), Pegler et al. (1995, 1997), Courtecuisse (1999), and Courtecuisse \& Duhem (2005). Some specimens, especially from the genera Cortinarius, Inocybe, Russula and L. laccata, were examined with a compound microscope to confirm their taxonomic identification from spores and to estimate the number of species within each group. Taxonomic classification of species was according to Kirk et al. (2001) and fungal nomenclature was based on Index Fungorum (http://www.indexfungorum.org/
Names/Names.asp). In addition to taxonomic identification, carpophores were categorized according to their trophic group (ectomycorrhizal, parasitic or saprotrophic fungi). After drying in air-vented ovens at $30^{\circ} \mathrm{C}$ for $72 \mathrm{hr}$, representative voucher specimens were deposited at the herbarium of Escola Superior Agrária of Instituto Politécnico de Bragança (Portugal).

\section{Data analysis}

Species richness, total abundance and relative abundance were assessed. Richness is the number of taxa collected each year and over all $4 \mathrm{y}$. Abundance is the total number of carpophores collected per species, whereas the relative abundance is the proportion of carpophores from each species in relation to the total number of carpophores recovered. Frequency of occurrence is given as the proportion of the number of days that each species was recovered to the total number of sampling days from Sep. 2002 to Dec. 2005.

Temperature and rainfall data were correlated with the number of species and total number of carpophores, from total or different trophic groups (ectomycorrhizal and saprotrophic fungi). All the Spearman correlation coefficients were determined using SAS v. 9.1.3. 


\section{Results}

\section{Fungal diversity}

During the whole study, 73 macrofungal species belonging to 16 families and 23 genera were identified (Table 1). The families that contained the most species were Russulaceae (19), Cortinariaceae (14), Tricholomataceae (13) and Boletaceae (7), which together accounted for about $73 \%$ of the total surveyed species. The greatest number of species belonged to the genera Russula (12), Inocybe (9), Lactarius (7), Tricholoma (6), Boletus (5), Cortinarius (5) and Amanita (5). The distribution of species by trophic groups revealed a dominance of ectomycorrhizal species (82\%) while saprotrophic and parasitic species were found in lower numbers.

A plot of the cumulative number of species over the four successive years appeared to be asymptotic and revealed that $80.5 \%$ of macrofungal species occurring within the study plots were recorded (Fig 2). The number of species collected during the present study varied between years, with most in 2002 (56 species) and 2003 (43 species) (Table 1). During the following years, the number of macrofungal species decreased, with least (12 species) in 2005. Harvestings from 2002 and 2003 contributed the most to the total fungal species richness. The number of new species decreased throughout the study period, with 56 species in the first study year, 12 additional species in the second year (2003), and only four new species in 2004 and one in 2005.

Overall the majority of species were ectomycorrhizal (EM), belong to the genera Russula, Inocybe and Cortinarius, but in 2005 , the majority of species were saprotrophic, belonging mainly to the genus Collybia (Table 1). In total 2677 carpophores were harvested $35 \%$ being from EM species L. laccata (324), H. crustuliniforme (308) and I. geophylla (303) (Table 1). As for species richness, the number of carpophores varied across the study's $4 \mathrm{yr}$, with the maximum in 2003 and the minimum in 2005 , accounting respectively for $57 \%$ and $5 \%$ of the total recorded during the whole study. The most abundant species also varied between years. The EM species L. laccata, $H$. crustuliniforme and C. cibarius being the most abundant in 2002, 2003 and 2004, respectively, and the saprotrophic Collybia dryophila being most abundant in 2005, accounting for nearly $45 \%$ of the total for that year.

\section{Fruiting phenology}

Fruiting phenology showed a bimodal pattern each year, with a peak from late May to Jun. (spring season) and another from Sep. to early Dec. (autumn season) (Fig 3). The number of carpophores and species collected in the autumn fruiting season were higher than in the spring fruiting season during the entire study period, but especially in 2002 and 2003. The spring fruiting season is characteristically very short - approximately 1 month duration. In contrast, though varying between years, the autumn fruiting season is more extensive, the peak number of species occurring in Oct. or Nov. The peak values for species richness and carpophore production in the autumn of 2004 and particularly in 2005 were much lower than in 2002 and 2003.

\section{Frequency of occurrence}

H. crustuliniforme, I. geophylla, L. laccata and Russula lutea were most frequently collected with more than $17 \%, 15 \%, 13 \%$ and $11 \%$ of the total sampling dates, respectively. Forty-six percent of the total macrofungal species had occurred in a single year. During 2002, 2003, 2004 and 2005, an exclusive number of 20, 10, 3 and 1 species, respectively, were collected solely in those years. Only about $4 \%$ of the species, L. perlatum, R. lutea and $R$. cyanoxantha, occurred in all $4 \mathrm{y}, 25 \%$ in $2 \mathrm{y}$ and $25 \%$ in $3 \mathrm{y}$.

Across all years $85 \%$ occurred solely during the autumn season (Fig 4). Only 11 species fruited in both spring and autumn and these belonged particularly to the genera Russula (R. cyanoxantha, R. lutea, R. odorata, R. risigallina, Russula sp.3), Lactarius (L. piperatus, L. volemus) and Boletus (B. aereus, B. edulis). Note, however, that these species (especially B. aereus, $R$. risigallina and L. volemus) were not always collected in both spring and autumn of the same year. Six species occurred more frequently in the spring than in the autumn season, especially C. cibarius, B. aereus and L. volemus, with a frequency of occurrence in the spring of $12.5 \%, 2.5 \%$ and $5 \%$, respectively, each comprising only $0.6 \%$ of the autumn fruitings.

During the autumn season, the most common species were $H$. crustuliniforme, I. geophylla and L. laccata, found in more than $21 \%, 18 \%$ and $17 \%$, respectively, of the total autumn sampling over the $4 \mathrm{yr}$ (Fig 4). During the spring fruiting season, $R$. risigallina and $C$. cibarius were most common, both being found in more than $12 \%$ of the total spring sampling over the $4 \mathrm{yr}$.

\section{Influence of weather on carpophore formation}

Correlation analysis, by determination of Spearman correlation coefficients (Table 2), indicated that the rainfall that occured from 3 to $30 \mathrm{~d}$ before sampling date was highly positively correlated with both species diversity and productivity. By contrast, the mean temperature occurring $3 \mathrm{~d}$ prior to sampling date was negatively correlated with carpophore production and fungal diversity. There was no correlation with temperature for other time intervals $(10,20$ or $30 \mathrm{~d})$. Similar results were obtained for minimum and maximum temperatures (data not shown).

When considering the trophic groups, no differences in Spearman correlation coefficients were found between temperatures and saprotrophic or EM fungi, but differences were found with rainfall (Table 2). Saprotrophic fungi displayed higher Spearman correlations values than EM fungi for all the time intervals studied. Additionally, for EM fungi the highest Spearman correlation value was with total rainfall occurring $30 \mathrm{~d}$ before sampling; whereas for saprotrophic fungi the highest correlation was with total rainfall that occurred $3 \mathrm{~d}$ before the sampling date.

\section{Discussion}

\section{Fungal diversity}

The present study, conducted from Sep. 2002 to Dec. 2005, is constituted the first systematically, long-term monitoring 
Table 1 - Total abundance (N) and percentage (\%) of each fungal species relative to the total number of carpophores collected in a Castanea sativa orchard from September 2002 to December 2005. The trophic group of fungal species is also shown (m - ectomycorrhizal; mg - ectomycorrhizal genus; s - saprotrophic; sg - saprotrophic genus; p - parasitic; ? - trophic group unclear)

\begin{tabular}{|c|c|c|c|c|c|c|c|c|c|c|c|}
\hline \multirow[t]{2}{*}{ Trophism } & \multirow[t]{2}{*}{ Family, genera and species } & \multicolumn{2}{|c|}{2002} & \multicolumn{2}{|c|}{2003} & \multicolumn{2}{|c|}{2004} & \multicolumn{2}{|c|}{2005} & \multicolumn{2}{|c|}{ Total } \\
\hline & & $\mathrm{N}$ & $\%$ & $\mathrm{~N}$ & $\%$ & $\mathrm{~N}$ & $\%$ & $\mathrm{~N}$ & $\%$ & $\mathrm{~N}$ & $\%$ \\
\hline & Agaricaceae & & & & & & & & & & \\
\hline & Macrolepiota & & & & & & & & & & \\
\hline $\mathrm{s}$ & M. mastoidea (Fr.) Singer & 0 & 0.00 & 6 & 0.40 & 0 & 0.00 & 1 & 0.72 & 7 & 0.26 \\
\hline \multirow[t]{3}{*}{$\mathrm{s}$} & M. procera (Scop.) Singer & 1 & 0.12 & 1 & 0.07 & 0 & 0.00 & 2 & 1.45 & 4 & 0.15 \\
\hline & Strophariaceae & & & & & & & & & & \\
\hline & Hebeloma & & & & & & & & & & \\
\hline $\mathrm{m}$ & H. crustuliniforme (Bull.) Quél. & 33 & 4.05 & 255 & 16.84 & 20 & 9.48 & 0 & 0.00 & 308 & 11.51 \\
\hline \multirow[t]{3}{*}{$\mathrm{mg}$} & Hebeloma sp.1 & 4 & 0.49 & 0 & 0.00 & 0 & 0.00 & 0 & 0.00 & 4 & 0.15 \\
\hline & Boletaceae & & & & & & & & & & \\
\hline & Boletus & & & & & & & & & & \\
\hline $\mathrm{m}$ & B. aereus Bull. & 4 & 0.49 & 0 & 0.00 & 1 & 0.47 & 0 & 0.00 & 5 & 0.19 \\
\hline $\mathrm{m}$ & B. edulis Bull. & 17 & 2.09 & 4 & 0.26 & 0 & 0.00 & 0 & 0.00 & 21 & 0.78 \\
\hline $\mathrm{m}$ & B. rhodoxanthus (Krombh.) Kall. & 0 & 0.00 & 4 & 0.26 & 0 & 0.00 & 0 & 0.00 & 4 & 0.15 \\
\hline $\mathrm{m}$ & B. satanoides Smotl. & 1 & 0.12 & 0 & 0.00 & 0 & 0.00 & 0 & 0.00 & 1 & 0.04 \\
\hline \multirow[t]{2}{*}{$\mathrm{mg}$} & Boletus sp.1 & 3 & 0.37 & 0 & 0.00 & 0 & 0.00 & 0 & 0.00 & 3 & 0.11 \\
\hline & Xerocomus & & & & & & & & & & \\
\hline $\mathrm{m}$ & X. chrysenteron (Bull.) Quél. & 21 & 2.58 & 4 & 0.26 & 0 & 0.00 & 1 & 0.72 & 26 & 0.97 \\
\hline \multirow[t]{3}{*}{$\mathrm{mg}$} & Xerocomus sp.1 & 1 & 0.12 & 0 & 0.00 & 0 & 0.00 & 0 & 0.00 & 1 & 0.04 \\
\hline & Cantharellaceae & & & & & & & & & & \\
\hline & Cantharellus & & & & & & & & & & \\
\hline $\mathrm{m}$ & C. cibarius Fr. & 3 & 0.37 & 0 & 0.00 & 93 & 44.08 & 24 & 17.39 & 120 & 4.48 \\
\hline \multirow[t]{3}{*}{$\mathrm{m}$} & C. melanoxeros Desm. & 0 & 0.00 & 2 & 0.13 & 0 & 0.00 & 0 & 0.00 & 2 & 0.07 \\
\hline & Cortinariaceae & & & & & & & & & & \\
\hline & Cortinarius & & & & & & & & & & \\
\hline $\mathrm{m}$ & C. anomalus (Fr.) Fr. & 19 & 2.33 & 15 & 0.99 & 0 & 0.00 & 0 & 0.00 & 34 & 1.27 \\
\hline $\mathrm{m}$ & C. diasemospermus Lamoure & 0 & 0.00 & 6 & 0.40 & 0 & 0.00 & 0 & 0.00 & 6 & 0.22 \\
\hline $\mathrm{m}$ & C. helobius Romagn. & 47 & 5.77 & 116 & 7.66 & 4 & 1.90 & 0 & 0.00 & 167 & 6.24 \\
\hline $\mathrm{m}$ & C. hinnuleus Fr. & 6 & 0.74 & 11 & 0.73 & 3 & 1.42 & 0 & 0.00 & 20 & 0.75 \\
\hline \multirow[t]{2}{*}{$\mathrm{mg}$} & Cortinarius sp.1 & 13 & 1.60 & 6 & 0.40 & 1 & 0.47 & 0 & 0.00 & 20 & 0.75 \\
\hline & Inocybe & & & & & & & & & & \\
\hline $\mathrm{m}$ & I. asterospora Quél. & 5 & 0.61 & 0 & 0.00 & 0 & 0.00 & 0 & 0.00 & 5 & 0.19 \\
\hline $\mathrm{m}$ & I. flocculosa (Berk.) Sacc. & 13 & 1.60 & 110 & 7.27 & 8 & 3.79 & 0 & 0.00 & 131 & 4.89 \\
\hline $\mathrm{m}$ & I. geophylla (Pers.) P. Kumm. & 47 & 5.77 & 216 & 14.27 & 40 & 18.96 & 0 & 0.00 & 303 & 11.32 \\
\hline $\mathrm{m}$ & I. geophylla var.lilacina Gillet & 3 & 0.37 & 1 & 0.07 & 0 & 0.00 & 0 & 0.00 & 4 & 0.15 \\
\hline $\mathrm{m}$ & I. geophylla var.lutescens Gillet & 0 & 0.00 & 15 & 0.99 & 0 & 0.00 & 0 & 0.00 & 15 & 0.56 \\
\hline $\mathrm{m}$ & I. glabripes Ricken & 68 & 8.35 & 0 & 0.00 & 0 & 0.00 & 0 & 0.00 & 68 & 2.54 \\
\hline $\mathrm{m}$ & I. maculata Boud. & 0 & 0.00 & 28 & 1.85 & 0 & 0.00 & 0 & 0.00 & 28 & 1.05 \\
\hline $\mathrm{m}$ & I. rimosa (Bull. Fr.) P. Kumm. & 90 & 11.06 & 53 & 3.50 & 0 & 0.00 & 0 & 0.00 & 143 & 5.34 \\
\hline $\mathrm{mg}$ & Inocybe sp.1 & 0 & 0.00 & 0 & 0.00 & 7 & 3.32 & 25 & 18.12 & 32 & 1.20 \\
\hline & Entolomataceae & & & & & & & & & & \\
\hline & Clitopilus & & & & & & & & & & \\
\hline $\mathrm{m}$ & C. prunulus (Scop.) Fr. & 9 & 1.11 & 4 & 0.26 & 0 & 0.00 & 0 & 0.00 & 13 & 0.49 \\
\hline & Fistulinaceae & & & & & & & & & & \\
\hline & Fistulina & & & & & & & & & & \\
\hline $\mathrm{s}(\mathrm{p} ?)$ & F. hepatica (Schaeff.) With. & 1 & 0.12 & 0 & 0.00 & 1 & 0.47 & 2 & 1.45 & 4 & 0.15 \\
\hline & Gyroporaceae & & & & & & & & & & \\
\hline & Gyroporus & & & & & & & & & & \\
\hline $\mathrm{m}$ & G. castaneus (Bull.) Quél. & 2 & 0.25 & 0 & 0.00 & 0 & 0.00 & 0 & 0.00 & 2 & 0.07 \\
\hline & Hydnaceae & & & & & & & & & & \\
\hline & Hydnum & & & & & & & & & & \\
\hline $\mathrm{m}$ & H. rufescens Pers. & 22 & 2.70 & 31 & 2.05 & 0 & 0.00 & 0 & 0.00 & 53 & 1.98 \\
\hline & Hydnangiaceae & & & & & & & & & & \\
\hline & Laccaria & & & & & & & & & & \\
\hline $\mathrm{m}$ & L. amethystina Cooke & 5 & 0.61 & 3 & 0.20 & 0 & 0.00 & 0 & 0.00 & 8 & 0.30 \\
\hline $\mathrm{m}$ & L. laccata (Scop.) Fr. & 114 & 14.00 & 210 & 13.87 & 0 & 0.00 & 0 & 0.00 & 324 & 12.10 \\
\hline & Leotiaceae & & & & & & & & & & \\
\hline & Leotia & & & & & & & & & & \\
\hline $\mathrm{s}$ & L. lubrica (Scop.) Pers. & 0 & 0.00 & 38 & 2.51 & 0 & 0.00 & 0 & 0.00 & 38 & 1.42 \\
\hline & & & & & & & & & (contin & d on $n$ & t page) \\
\hline
\end{tabular}




\begin{tabular}{|c|c|c|c|c|c|c|c|c|c|c|c|}
\hline \multirow[t]{2}{*}{ Trophism } & \multirow[t]{2}{*}{ Family, genera and species } & \multicolumn{2}{|c|}{2002} & \multicolumn{2}{|c|}{2003} & \multicolumn{2}{|c|}{2004} & \multicolumn{2}{|c|}{2005} & \multicolumn{2}{|c|}{ Total } \\
\hline & & $\mathrm{N}$ & $\%$ & $\mathrm{~N}$ & $\%$ & $\mathrm{~N}$ & $\%$ & $\mathrm{~N}$ & $\%$ & $\mathrm{~N}$ & $\%$ \\
\hline & $\begin{array}{l}\text { Lycoperdaceae } \\
\text { Lycoperdon }\end{array}$ & & & & & & & & & & \\
\hline $\mathrm{s}$ & $\begin{array}{l}\text { L. perlatum Pers. } \\
\text { Pluteaceae } \\
\text { Amanita }\end{array}$ & 5 & 0.61 & 22 & 1.45 & 1 & 0.47 & 5 & 3.62 & 33 & 1.23 \\
\hline $\mathrm{m}$ & A. caesarea (Scop.) Pers. & 0 & 0.00 & 0 & 0.00 & 1 & 0.47 & 0 & 0.00 & 1 & 0.04 \\
\hline $\mathrm{m}$ & A. gemmata (Fr.) Bertill. & 9 & 1.11 & 0 & 0.00 & 0 & 0.00 & 0 & 0.00 & 9 & 0.34 \\
\hline $\mathrm{m}$ & A. pantherina Gonn. \& Rabenh. & 1 & 0.12 & 0 & 0.00 & 0 & 0.00 & 0 & 0.00 & 1 & 0.04 \\
\hline $\mathrm{m}$ & A. spissa (Fr.) P. Kumm. & 1 & 0.12 & 0 & 0.00 & 0 & 0.00 & 0 & 0.00 & 1 & 0.04 \\
\hline $\mathrm{m}$ & $\begin{array}{l}\text { A. vaginata (Bull.) Lam. } \\
\text { Russulaceae } \\
\text { Lactarius }\end{array}$ & 18 & 2.21 & 0 & 0.00 & 0 & 0.00 & 0 & 0.00 & 18 & 0.67 \\
\hline $\mathrm{m}$ & L. chrysorrheus Fr. & 4 & 0.49 & 0 & 0.00 & 0 & 0.00 & 0 & 0.00 & 4 & 0.15 \\
\hline $\mathrm{m}$ & L. piperatus (L.) Pers. & 28 & 3.44 & 10 & 0.66 & 3 & 1.42 & 0 & 0.00 & 41 & 1.53 \\
\hline $\mathrm{m}$ & L. vellereus (Fr.) Fr. & 0 & 0.00 & 18 & 1.19 & 0 & 0.00 & 0 & 0.00 & 18 & 0.67 \\
\hline $\mathrm{m}$ & L. volemus (Fr.) Fr. & 2 & 0.25 & 1 & 0.07 & 1 & 0.47 & 0 & 0.00 & 4 & 0.15 \\
\hline $\mathrm{mg}$ & Lactarius sp.1 & 3 & 0.37 & 0 & 0.00 & 0 & 0.00 & 0 & 0.00 & 3 & 0.11 \\
\hline $\mathrm{mg}$ & Lactarius sp. 2 & 3 & 0.37 & 0 & 0.00 & 0 & 0.00 & 0 & 0.00 & 3 & 0.11 \\
\hline $\mathrm{mg}$ & $\begin{array}{l}\text { Lactarius sp.3 } \\
\text { Russula }\end{array}$ & 4 & 0.49 & 0 & 0.00 & 0 & 0.00 & 0 & 0.00 & 4 & 0.15 \\
\hline $\mathrm{m}$ & R. amoenolens Romagn. & 16 & 1.97 & 1 & 0.07 & 0 & 0.00 & 0 & 0.00 & 17 & 0.64 \\
\hline $\mathrm{m}$ & R. chloroides (Krombh.) Bres. & 1 & 0.12 & 0 & 0.00 & 0 & 0.00 & 0 & 0.00 & 1 & 0.04 \\
\hline $\mathrm{m}$ & R. cyanoxantha (Schaeff.) Fr. & 1 & 0.12 & 2 & 0.13 & 2 & 0.95 & 4 & 2.90 & 9 & 0.34 \\
\hline $\mathrm{m}$ & R. delica Fr. & 23 & 2.83 & 12 & 0.79 & 1 & 0.47 & 0 & 0.00 & 36 & 1.34 \\
\hline $\mathrm{m}$ & R. foetens Pers. & 27 & 3.32 & 1 & 0.07 & 4 & 1.90 & 0 & 0.00 & 32 & 1.20 \\
\hline $\mathrm{m}$ & R. lutea Vent. & 16 & 1.97 & 59 & 3.90 & 1 & 0.47 & 2 & 1.45 & 78 & 2.91 \\
\hline $\mathrm{m}$ & R. nigricans (Bull.) Fr. & 3 & 0.37 & 0 & 0.00 & 0 & 0.00 & 0 & 0.00 & 3 & 0.11 \\
\hline $\mathrm{m}$ & R. odorata Romagn. & 21 & 2.58 & 16 & 1.06 & 0 & 0.00 & 0 & 0.00 & 37 & 1.38 \\
\hline $\mathrm{m}$ & R. risigallina (Batsch) Sacc. & 14 & 1.72 & 9 & 0.59 & 5 & 2.37 & 0 & 0.00 & 28 & 1.05 \\
\hline $\mathrm{mg}$ & Russula sp.1 & 13 & 1.60 & 9 & 0.59 & 1 & 0.47 & 0 & 0.00 & 23 & 0.86 \\
\hline $\mathrm{mg}$ & Russula sp.2 & 1 & 0.12 & 3 & 0.20 & 0 & 0.00 & 0 & 0.00 & 4 & 0.15 \\
\hline $\mathrm{mg}$ & $\begin{array}{l}\text { Russula sp. } 3 \\
\text { Strophariaceae } \\
\text { Hypholoma }\end{array}$ & 0 & 0.00 & 0 & 0.00 & 6 & 2.84 & 0 & 0.00 & 6 & 0.22 \\
\hline $\mathrm{s}(\mathrm{p} ?)$ & $\begin{array}{l}\text { H. fasciculare (Huds.) Quél. } \\
\text { Tricholomataceae } \\
\text { Calocybe }\end{array}$ & 5 & 0.61 & 16 & 1.06 & 0 & 0.00 & 0 & 0.00 & 21 & 0.78 \\
\hline $\mathrm{s}$ & $\begin{array}{l}\text { C. gambosa (Fr.) Donk } \\
\text { Clitocybe }\end{array}$ & 0 & 0.00 & 11 & 0.73 & 0 & 0.00 & 0 & 0.00 & 11 & 0.41 \\
\hline $\mathrm{s}$ & C. gibba (Pers.) P. Kumm. & 1 & 0.12 & 0 & 0.00 & 1 & 0.47 & 0 & 0.00 & 2 & 0.07 \\
\hline sg & $\begin{array}{l}\text { Clitocybe sp.1 } \\
\text { Collybia }\end{array}$ & 0 & 0.00 & 0 & 0.00 & 2 & 0.95 & 0 & 0.00 & 2 & 0.07 \\
\hline $\mathrm{s}$ & C. butyracea (Bull.) Fr. & 0 & 0.00 & 7 & 0.46 & 0 & 0.00 & 0 & 0.00 & 7 & 0.26 \\
\hline $\mathrm{s}$ & C. dryophila (Bull.) P. Kumm. & 1 & 0.12 & 0 & 0.00 & 0 & 0.00 & 62 & 44.93 & 63 & 2.35 \\
\hline $\mathrm{s}$ & $\begin{array}{l}\text { C. marasmioides (Britzelm.) Bresinsky \& Stangl } \\
\text { Mycena }\end{array}$ & 0 & 0.00 & 7 & 0.46 & 0 & 0.00 & 3 & 2.17 & 10 & 0.37 \\
\hline sg & $\begin{array}{l}\text { Mycena sp.1 } \\
\text { Tricholoma }\end{array}$ & 0 & 0.00 & 0 & 0.00 & 0 & 0.00 & 7 & 5.07 & 7 & 0.26 \\
\hline $\mathrm{m}$ & T. acerbum (Bull.) Vent. & 23 & 2.83 & 60 & 3.96 & 2 & 0.95 & 0 & 0.00 & 85 & 3.18 \\
\hline $\mathrm{m}$ & T. ustale (Fr.) P. Kumm. & 6 & 0.74 & 105 & 6.94 & 2 & 0.95 & 0 & 0.00 & 113 & 4.22 \\
\hline $\mathrm{m}$ & T. ustaloides Romagn. & 0 & 0.00 & 6 & 0.40 & 0 & 0.00 & 0 & 0.00 & 6 & 0.22 \\
\hline $\mathrm{mg}$ & Tricholoma sp.1 & 5 & 0.61 & 0 & 0.00 & 0 & 0.00 & 0 & 0.00 & 5 & 0.19 \\
\hline $\mathrm{mg}$ & Tricholoma sp.2 & 2 & 0.25 & 0 & 0.00 & 0 & 0.00 & 0 & 0.00 & 2 & 0.07 \\
\hline $\mathrm{mg}$ & Tricholoma sp. 3 & 5 & 0.61 & 0 & 0.00 & 0 & 0.00 & 0 & 0.00 & 5 & 0.19 \\
\hline & Total & 814 & 100.0 & 1514 & 100.0 & 211 & 100.0 & 138 & 100.0 & 2677 & 100.0 \\
\hline
\end{tabular}

(seven consecutive fruiting seasons) of carpophore production in chestnut plantations.

The high diversity of macrofungal species associated with sweet-chestnut plantations, 73 species belonging to 16 families and 23 genera with 2677 carpophores, is less than in previous studies in southern Tuscany (Italy) (Laganà et al. 2002a) and in Greece (Diamandis \& Perlerou 2001) (153 and 168 species, respectively), but greater than a study in Romania (25 species) (Chira \& Chira 2003). Several factors could explain this fact: differences in sampling methods, differences among 


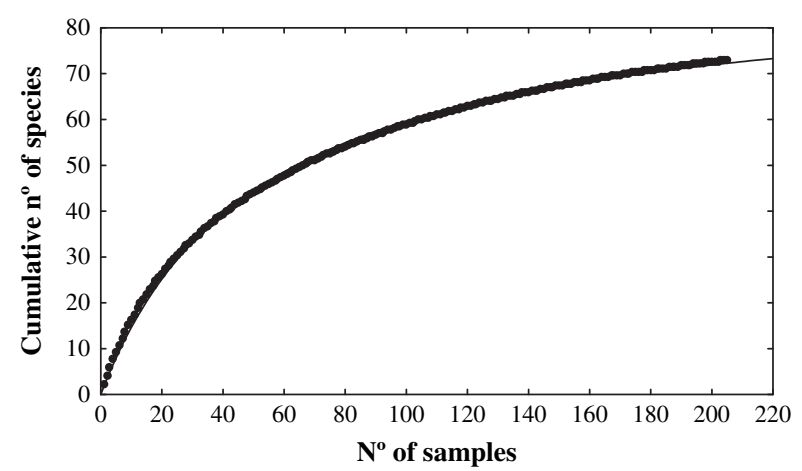

Fig 2 - Cumulative number of species collected over the 4-y study (73 species, 205 samples).

chestnut stand in age (Smith et al. 2002), composition (Ferris et al. 2000), soil (Conn \& Dighton 2000) and microclimate conditions. However, the exploitation patterns of the various chestnut stands were probably the main cause of the difference. The surveys in Tuscany and Greece were in chestnut coppiced for timber production, characterized by a high density of trees (Diamandis \& Perlerou 2001; Laganà et al. 2002a), as opposed to our orchard for fruit production with a low density of trees - $12 \mathrm{~m}$ apart - and with greater anthropogenic influence, e.g. trampling of the orchard floor associated with mushroom harvesting. As previously reported (Egli et al. 2006), trampling can reduce fruit body production to

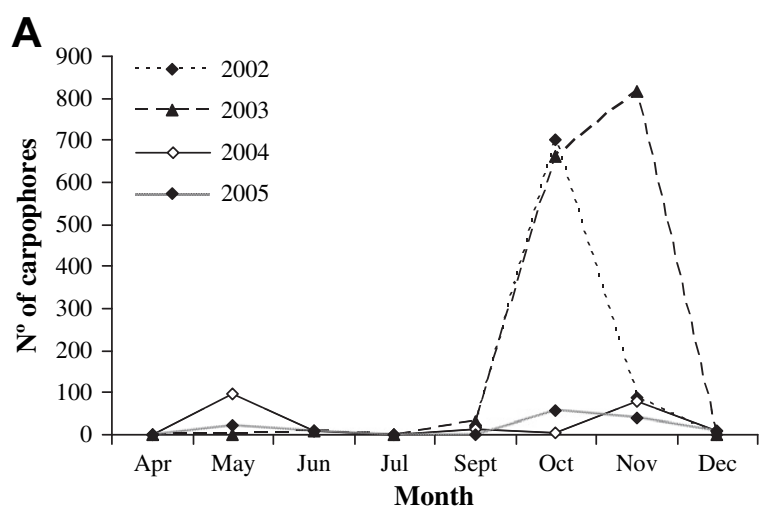

B

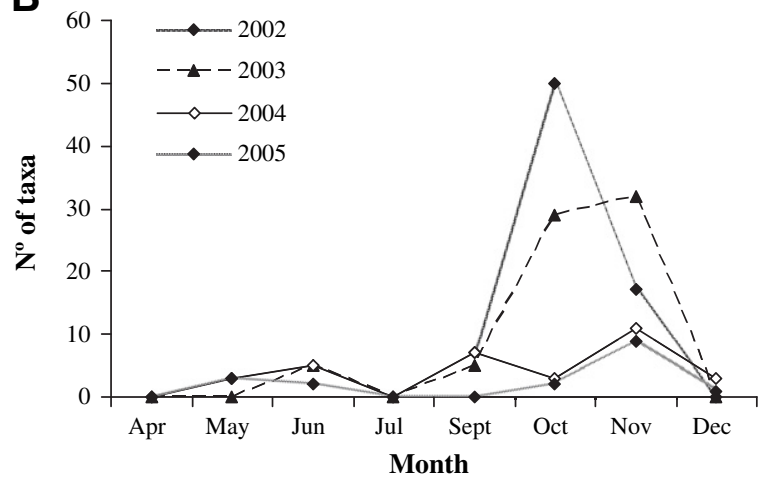

Fig 3 - (A) Fruiting phenology of carpophore occurrence (B) number of macrofungal species during the survey period (from Sep. 2002 to Dec. 2005). about $70 \%$ and reduce the mean number of fruiting species per year.

Although there were differences in species richness, the most common genera in our study were also commonly found in the few other studies in C. sativa stands, the genera Russula, Inocybe, Lactarius, Tricholoma, Cortinarius and Amanita being the largest in terms of species number (Diamandis \& Perlerou 2001; Laganà et al. 2002a; Chira \& Chira 2003). In our study, the three most abundant species were ectomycorrhizal, namely L. laccata, I. geophylla and H. crustuliniforme, producing around $35 \%$ of all carpophores. However, abundance of mycorrhizal mycelium and root tips may be different, as seen in studies examining the below-ground mycorrhizal communities using molecular approaches (Gardes \& Bruns 1996b; Richard et al. 2005; Smith et al. 2007). The contrasting patterns are suggested to be a consequence of many fungal species being unable to produce fruitbodies or to produce inconspicuous ones. Other explanations include large differences in reproductive and explorative strategies among fungi. In addition, the optimum fruiting conditions for some species may not have occurred in the studied years. Despite these limitations, the current fruitbody survey is still a useful way to assess the fungal diversity in the chestnut orchard providing a general picture. Overall, at the genus level, three main patterns emerge: (i) species-rich and highly productive genera, e.g., Inocybe, Russula, Cortinarius and Tricholoma (about $44 \%$ of the taxonomic diversity and $55 \%$ of all fruitbody production), (ii) species-rich but unproductive genera, e.g., Lactarius, Boletus and Amanita (about $23 \%$ of the taxonomic diversity and $5 \%$ of all fruitbody production); and (iii) species-poor but highly productive genera, e.g., Laccaria and Hebeloma (about $5.5 \%$ of the taxonomic diversity and $24 \%$ of all fruitbody production).

Species of Russula, Cortinarius and Inocybe have frequently been described as dominant in several old-growth forests containing Pseudotsuga menziesii (Smith et al. 2002) and Quercus ilex (Richard et al. 2004). Furthermore, those studies showed that the EM species L. laccata is one of the three most abundant species, as also seen in our study. The similarities between fungal taxa on these very different ecosystems may reflect the fact that they encompass species with diverse ecological requirements (Richard et al. 2004).

From the total number of macrofungal species found in our study, $82 \%$ were EM species and the remaining were saprotrophic (15\%) and saprotrophic/parasitic (3\%) species. A high percentage of EM species in chestnut stands has been previously reported in southern Tuscany (Italy) where $60 \%$ of the 153 identified fungal species were EM (Laganà et al. 2002a). Although we have only identified 73 species, the relative abundance of EM species should be considered high, since the cumulative number of species over the four successive years suggested that $80.5 \%$ of macrofungal species that probably exist in this habitat were surveyed. The high percentage of EM species registered in our study could be due to the age of the chestnut trees, which was over $100 \mathrm{y}$ old. The number of EM species present in a given ecosystem is dependent on the host plant's age (Mason et al. 1982; Dighton \& Mason 1985; Kernaghan 2005), increasing gradually with host plant age (Luoma et al. 1991; Keizer \& Arnolds 1994; Smith et al. 2002). Also, some studies on the succession of EM fungi have indicated that there are fungi that are characteristic of early-stage and of late-stage 


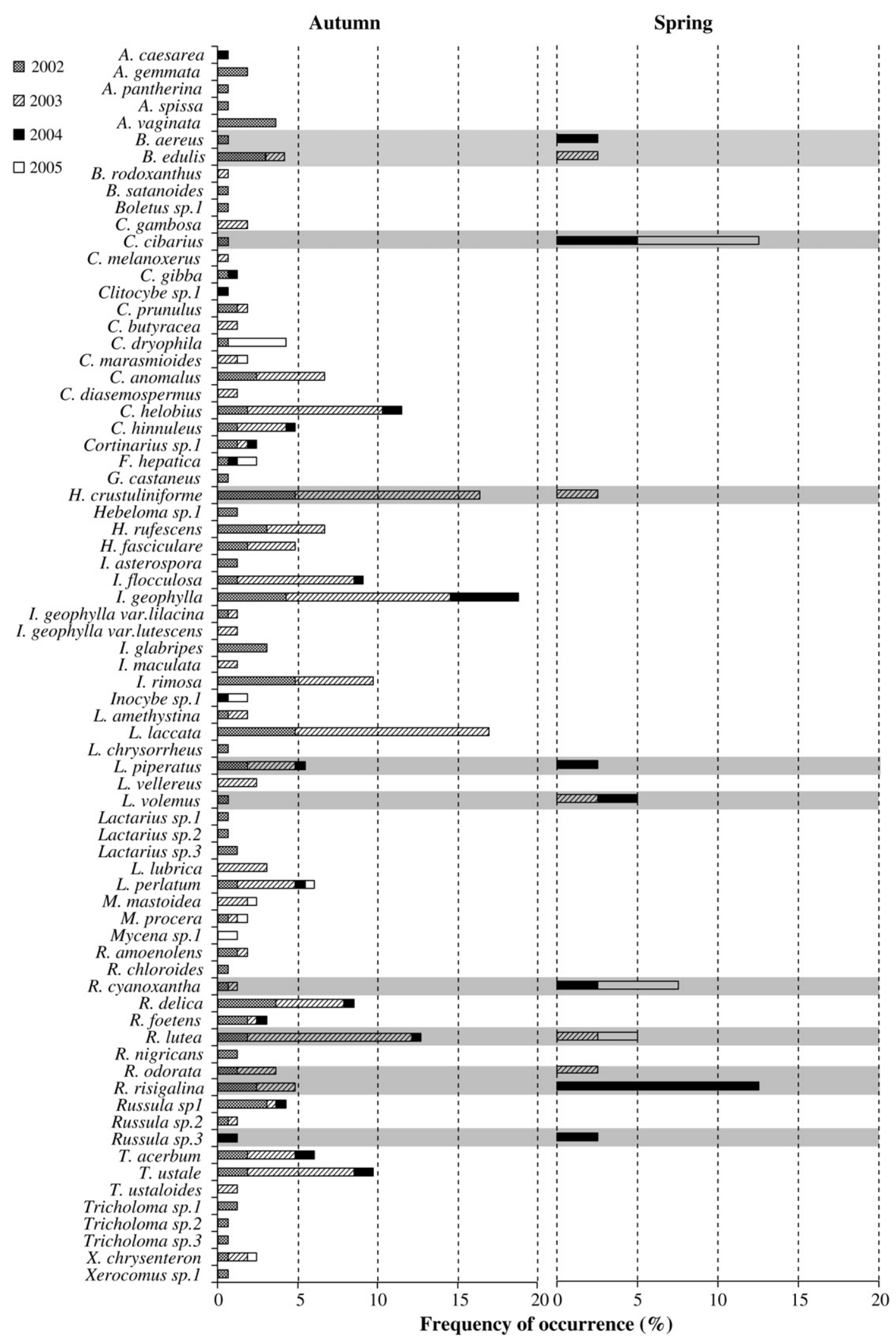

Fig 4 - Frequency of occurrence of macrofungal species collected over the 4-y during autumn and spring seasons [autumn fruiting season: $2002(n=15), 2003(n=60), 2004(n=45), 2005(n=45)$; spring fruiting season: $2003(n=10), 2004(n=15)$, $2005(n=15)]$. 
Table 2 - Spearman correlation coefficients between number of species and sporocarps (total, ectomycorrhizal and saprotrophic), surveyed over the four-years, and mean temperature or total rainfall. These correlations were performed using the weather data collected 3-, 10-, 20- and 30-days before the sampling date

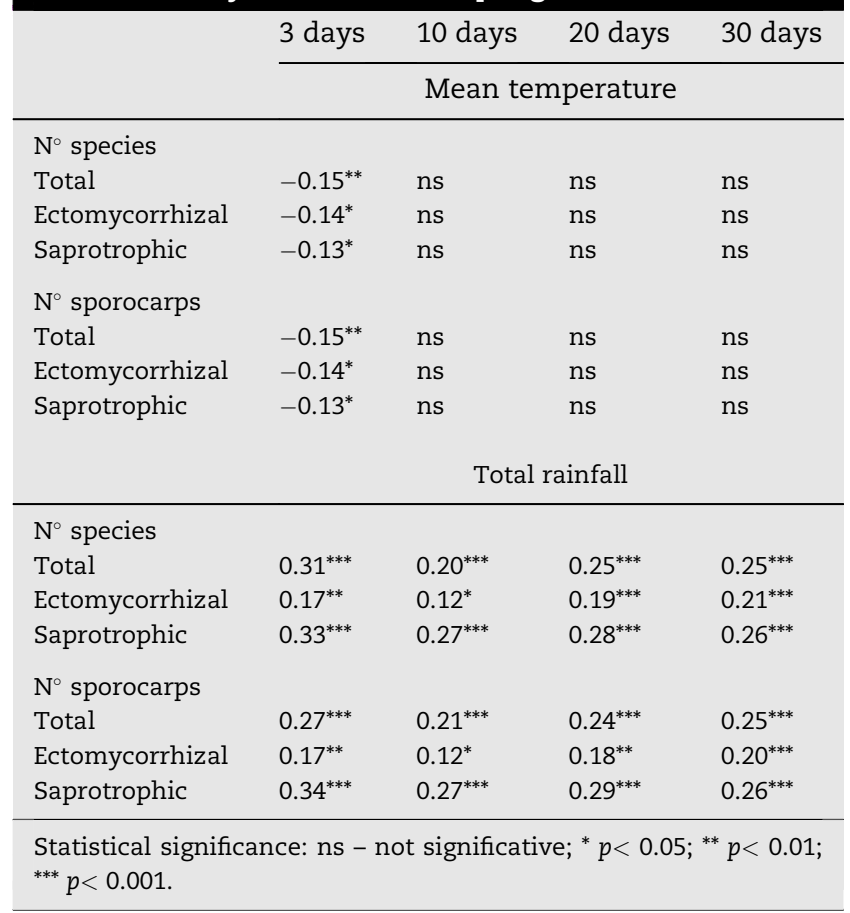

agro-forest stands (Arnolds 1991; Matsuda \& Hijii 1998; SennIrlet \& Bieri 1999; Smith et al. 2002; Nara et al. 2003). The genera Russula and Cortinarius are considered to be late-stage fungi (Matsuda \& Hijii 1998; Nara et al. 2003). Accordingly, these genera were the most represented in our chestnut orchard.

\section{Fruiting conditions and phenology}

In our study, species richness as well as number of carpophores varied between years. The decrease in number of species and carpophores from 2002 and 2003 to 2005 may be due to a variation of weather conditions, as previously suggested by other authors (Eveling et al. 1990; Laganà et al. 2002b). In Portugal, particularly in the Trás-os-Montes region, 2004 and 2005 were relatively dry years with a total rainfall from Apr. to Dec. of 330 and $315 \mathrm{~mm}$, respectively. Previous years had nearly $450 \mathrm{~mm}$ for the same period. The weather impact on macrofungal fruiting was supported by the correlation analysis using Spearman coefficients. While the rainfall favored the diversity and productivity of fruit bodies, temperature (mean, maximum and minimum) was not highly correlated, though there was a significant negative effect between temperature in the $3 \mathrm{~d}$ preceding sampling and carpophores.

The preponderance of EM species and carpophores collected in all the years except in 2005, when the saprotrophic, C. dryophila, was most abundant may result from different responses between EM fungi and saprobes to rainfall. C. dryophila was collected only in Oct., with a high number of carpophores recovered on two sampling dates in that month.
This was the only autumn month with high rainfall following dry conditions. This is supported by the results obtained from the correlation analysis, which showed that rainfall occurring $3 \mathrm{~d}$ before sampling has more influence on the fruiting of saprotrophic than on EM fungi. The response of saprotrophic fungi to rapid weather changes may be related to their mycelia being found in surface soil/litter, in contrast to mycelia from EM fungi, which is usually deeper in the soil or humus layer (Salerni et al. 2002).

A major problem for the accurate definition of macrofungal communities in a particular site is related to carpophore production dependency on weather conditions and the sporadic fruiting of species (Ferris et al. 2000). Weekly surveys throughout the fruiting season (autumn and spring) over the four successive years will reflect species richness at our study site better than shorter less intensive studies. Finding additional species in every subsequent sampling year from 2002 to 2005 (20, 10, 3 and 1 species, respectively), is in agreement with other studies that recommended long-term monitoring to assess fungal species (Vogt et al. 1992; Dahlberg et al. 1997; Smith et al. 2002).

There was greatest fruiting (species and carpophores) during the autumn (Sep. to the beginning of Dec.) season and some fruiting in spring (late May to late Jun.), coinciding with the times of year when the temperature was mild and the rainfall abundant. This together with the correlation analysis, suggests that fruiting phenology of macrofungal species is directly related with weather conditions, especially with rainfall. Similar results have been reported by several authors (Eveling et al. 1990; Jennings \& Lysek 1996; Jonsson et al. 2000; Laganà et al. 2002b; Salerni et al. 2002), and climate change appears to be having dramatic effects on fungal phenology in the UK and Norway (Gange et al. 2007; Kauserud et al. 2008; Moore et al. 2008).

\section{Frequency of occurrence}

In our study, $46 \%$ of the surveyed species occurred in a single year and only $4 \%$ of the surveyed species occurred in all $4 \mathrm{y}$ of the study, namely L. perlatum, R. lutea and $R$. cyanoxantha. The infrequent fructification of most fungal species is a common phenomenon (Arnolds 1995; Watling 1995; O’Dell et al. 1999; Smith et al. 2002, Martínez de Aragón et al. 2007). Sporadic fruiting may be due to: (i) species fruiting in response to specific weather conditions; and (ii) species that fruit in intervals of 2 or $3 y$, this being the periodicity regulated by biological cycles almost unknown (O’Dell et al. 1999).

Most of the macrofungal species surveyed ( $85 \%$ ) have been collected exclusively in the autumn fruiting season, the others fruit in both spring and autumn. The species that occur in autumn probably have the highest need for precipitation and lower temperature needs than species that occur in the spring fruiting season. Biological cycles and the genetic background of species could also regulate fruiting season ability (Guinberteau \& Courtecuisse 1997). Furthermore, the physiological status of the plants may also have an influence on this phenomenon (Brundrett et al. 1996), since the exclusivity of fungi fruiting in autumn was mainly observed in EM species. Further evidence for plants exerting control of fruiting in their 
mycorrhizal partners comes from an analysis of a $50 \mathrm{y}$ data set, which revealed that in the UK since 1978, fungi that are EM with both conifers and angiosperms now fruit later in autumn when associated with the latter, reflecting the fact that angiosperms now remain in leaf much longer (Gange et al. 2007). This same study revealed an increase in decomposer fungi fruiting in spring, which may reflect increased activity in winter and spring as a result of climate change (Gange et al. 2007; Moore et al. 2008).

\section{Conclusion}

The survey has demonstrated that chestnut orchards provide a habitat for diverse macrofungal species not least EM species. Species richness and carpophore abundance fluctuates over time, which is likely related to weather conditions. The information obtained can be used as a baseline to discern future trends associated with climate change, and to interpret trends resulting from mushroom harvesting and management, and is therefore important for management, and conservation strategies and the conservation policy. Knowledge of the diversity and ecology of macrofungi can also be used as a bioassay of ecosystem health. In this context, there will also be a need to study the impact of mycorrhizal colonization on $C$. sativa sustainability and its resilience to natural and anthropogenic disturbance, such as water limitation or tillage practices.

\section{Acknowledgements}

This work was partially supported by Project AGRO 689: Agronomic, economic and environmental interest of macrofungi associated with pine (Pinus pinaster), chestnut (Castanea sativa) and oak (Quercus pyrenaica) trees in Northeast Portugal: Production of mycorrhizal pine, chestnut and oak plants.

\section{R E F E R E N C E S}

Agroconsultores, Coba, 1991. Carta dos solos, carta do uso actual da terra e carta da aptidão da terra do nordeste de Portugal. Projecto de desenvolvimento rural integrado de Trás-os-Montes. Universidade de Trás-os-Montes e Alto Douro, Portugal.

Alessio CL, 1985. Boletus Dill. ex L. Fungi Europaei, vol 2. Libreria Editrice Giovanna Biella, Saronno.

Anonymous, 2006. FAOSTAT: FAO statistical database. Agriculture data. Available from: <http://faostat.fao.org/>

Anonymous, 2007. Estatísticas Agrícolas 2006. Instituto Nacional de Estatísticas, Lisboa, Portugal.

Arnolds E, 1991. Decline of ectomycorrhizal fungi in Europe. Agriculture, Ecosystems and Environment 35: 209-244.

Arnolds E, 1995. Problems in Measurements of Species Diversity of Macrofungi. CAB International, Netherlands.

Baptista P, Martins A, Tavares R, Lino-Neto T, 2007. Macrofungi associated with sweet chestnut: a source of income for rural populations in Northeast of Portugal. In: Anonymous (Ed.), 1st World Conference on the Conservation and Sustainable Use of Wild
Fungi. Junta de Andalucia - Consejeria de Medio Ambiente, Córdoba, Spain, pp. 175-177.

Bas C, Kuyper THW, Noordeloos ME, Vellinga EC, 1990-2001. Flora Agaricina Neerlandica: Critical Monographs on Families of Agarics and Boleti Occurring in the Netherlands, vols 1-5. A.A. Balkema, Rotterdam, Broakfield.

Bon M, 1988. Guia de campo de los hongos de Europa. Ediciones Omega, Barcelona.

Branzanti MB, Rocca E, Pisi A, 1999. Effect of ectomycorrhizal fungi on chestnut ink disease. Mycorrhiza 9: 103-109.

Breitenbach J, Kränzlin F, 1984-2000. Champignons de Suisse, vols 1-5. Mykologia Lucern, Lucern.

Brundrett M, Bougher N, Dell B, Grove T, Malajczuk N, 1996. Working with mycorrhizas in forestry and agriculture. ACIAR Monograph No. 32. CSIRO Publishing, Canberra, Australia.

Candusso M, Lanzoni G, 1990. Lepiota s.l. Fungi Europaei. Libreria Editrice Giovanna Biella, Saronno.

Chira F, Chira D, 2003. Contribution to the knowledge of mycorrhizal fungi of chestnut forests of Baia Maré Forest District. Revista de Silvicultura si Cinegetica 17-18: 83-84.

Conn C, Dighton J, 2000. Litter quality influences on decomposition, ectomycorrhizal community structure and mycorrhizal root surface acid phosphatase activity. Soil Biology \& Biochemistry 32: 489-496.

Courtecuisse R, 1999. Mushrooms of Britain and Europe. HarperCollins Publishers, London.

Courtecuisse R, Duhem B, 2005. Guía de los hongos de la Península Ibérica, Europa y Norte de África. Ediciones Omega, Barcelona.

Dahlberg A, Jonsson L, Nylund J-E, 1997. Species diversity and distribution of biomass above and below ground among ectomycorrhizal fungi in an old-growth Norway spruce forest in south Sweden. Canadian Journal of Botany 75: 1323-1335.

Diamandis S, Perlerou C, 2001. The mycoflora of the chestnut ecosystems in Greece. Forest Snow and Landscape Research 76: 499-504.

Dighton J, Mason PA, 1985. Mycorrhizal dynamics during forest tree development. In: Moore, D., Casselton, L.A., Wood, D.A., Frankland, J.C. (Eds), Developmental Biology of Higher Fungi. Cambridge University Press, New York, pp. 117-139.

Egli S, Peter M, Buser C, Stahel W, Ayer F, 2006. Mushroom picking does not impair future harvests - results of a long-term study in Switzerland. Biological Conservation 129: 271-276.

Eveling DW, Wilson RN, Gillespie ES, Bataille A, 1990. Environmental effects on carpophore counts over fourteen years in a forest area. Mycological Research 94: 998-1002.

FAO-Unesco-Isric, 1988. Soil Map of the World. revised legend. World Soil Resources Report $n^{\circ}$ 60. FAO, Rome.

Ferris R, Peace AJ, Newton AC, 2000. Macrofungal communities of lowland Scots pine (Pinus sylvestris L.) and Norway spruce (Picea abies (L.) Karsten.) plantations in England: relationships with site factors and stand structure. Forest Ecology and Management 131: 255-267.

Gange AC, Gange EG, Sparks TH, Boddy L, 2007. Rapid and recent changes in fungal fruiting patterns. Science 316: 71.

Gardes M, Bruns TD, 1996a. ITS-RFLP matching for identification of fungi. In: Clapp, E.J. (Ed.), Methods in Molecular Biology, Vol 50. Humana Press Inc., Totowa, NJ, pp. 177-186.

Gardes M, Bruns TD, 1996b. Community structure of ectomycorrhizal fungi in a Pinus muricata forest: above- and below-ground views. Canadian Journal of Botany 74: 1572-1583.

Guinberteau J, Courtecuisse R, 1997. Diversité des champignons (surtout mycorhiziens) dans les écosystèmes forestiers actuels. Reuue Forestière Française XLIX: 25-39.

Harley JL, Harley EL, 1987. A check-list of mycorrhiza in the British flora. New Phytologist 105: 1-102.

Horton TR, Bruns TE, 2001. The molecular revolution in ectomycorrhizal ecology: peeking into the black-box. Molecular Ecology 10: 1855-1871. 
Jennings DH, Lysek G, 1996. Fungal Biology: understanding the fungal lifestyle. BIOS Scientific Publishers, Oxford.

Jonsson L, Dahlberg A, Brandrud TE, 2000. Spatiotemporal distribution of an ectomycorrhizal community in an oligotrophic Swedish Picea abies forest subjected to experimental nitrogen addition: above- and below-ground views. Forest Ecology and Management 132: 143-156.

Kauserud H, Stige LC, Vik JO, Økland RH, Høiland K, Stenseth NC, 2008. Mushroom fruiting and climate change. Proceedings of the National Academy of Sciences of the United States of America 105: 3811-3814.

Keizer PJ, Arnolds E, 1994. Succession of ectomycorrhizal fungi in roadside verges planted with common oak (Quercus robur L.) in Drenthe, The Netherlands. Mycorrhiza 4: 147-159.

Kernaghan G, 2005. Mycorrhizal diversity: cause and effect? Pedobiologia 49: 511-520.

Kirk PM, Cannon PF, David JC, Stalpers JA, 2001. Ainsworth \& Bisby's Dictionary of the Fungi. CABI Bioscience, UK.

Laganà A, Salerni E, Barluzzi C, Perini C, De Dominicis V, 2002a. Macrofungi as long-term indicators of forest health and management in central Italy. Cryptogomie Mycologie 23: 39-50.

Laganà A, Angiolini C, Loppi S, Salerni E, Perini C, Barluzzi C, De Dominicis V, 2002b. Periodicity, fluctuations and successions of macrofungi in fir forest (Abies alba Miller) in Tuscany, Italy. Forest Ecology and Management 169: 187-202.

Luoma DL, Frenkel RE, Trappe JM, 1991. Fruiting of hypogeous carpophores in Oregon Douglas-fir forests: seasonal and habitat variation. Mycologia 83: 335-353.

Marchand A, 1971-1986. Champignons du Nord et du Midi, vols 1-9. Société Mycologique des Pyrénées Méditerranéennes, Perpignan.

Martínez de Aragón J, Bonet JA, Fischer CR, Colinas C, 2007. Productivity of ectomycorrhizal and selected edible saprotrophic fungi in pine forests of the pre-Pyrenees mountains, Spain: predictive equations for forest management of mycological resources. Forest Ecology and Management 252: 239-256.

Martins A, 1997. Micorrização in vitro de plantas micropropagadas de castanheiro (Castanea sativa Mill). Série de Estudos Escola Superior Agrária. Instituto Politécnico de Bragança, Bragança, Portugal.

Martins A, 2004. Micorrização controlada de Castanea sativa Mill.: aspectos fisiológicos da micorrização in vitro e ex vitro. Tese de Doutoramento. Faculdade de Ciências da Universidade de Lisboa, Lisboa, Portugal.

Martins A, Casimiro A, Pais MMS, 1997. Influence of mycorrhization on physiological parameters of micropropagated Castanea sativa Mill. plants. Mycorrhiza 7: 161-165.

Martins L, Castro J, Macedo W, Marques C, Abreu C, 2007. Assessment of the spread of chestnut ink disease using remote sensing and geostatistical methods. European Journal of Plant Pathology 119: 159-164.

Mason PA, Last FT, Pelham J, Ingleby K, 1982. Ecology of some fungi associated with an ageing stand of birches (Betula pendula and B. pubescens). Forest Ecology and Management 4: 19-39.

Matsuda Y, Hijii N, 1998. Spatiotemporal distribution of fruitbodies of ectomycorrhizal fungi in an Abies firma forest. Mycorrhiza 8: 131-138.

Molina R, Pilz D, Smith J, Dunham S, Dreisbach T, O’Dell T, Castellano M, 2001. Conservation and management of forest fungi in the Pacific Northwestern United States: an integrated ecosystem approach. In: Moore, D., Nauta, M.M., Rotheroe, M. (Eds), Fungal Conservation: Issues and Solutions. Cambridge University Press, Cambridge, UK, pp. 19-63.

Moore D, Gange AC, Gange EG, Boddy L, 2008. Fruit bodies: their production and development in relation to environment. In: Boddy, L., Frankland, J.C., van West, P. (Eds), Ecology of Saprotrophic Basidiomycetes. Elsevier, Amsterdam, pp. 79-102.

Moser M, 1983. Keys to Agarics and Boleti (Polyporales, Boletales, Agaricales, Russulales). Mad River Pr Inc, London.

Nara K, Nakaya H, Hogetsu T, 2003. Ectomycorrhizal carpophore succession and production during early primary succession on Mount Fuji. New Phytologist 158: 193-206.

Noordeloos ME, 1988-2001. Flora Agaricina Neerlandica: Critical Monographs on Families of Agarics and Boleti occurring in the Netherlands, vols 1-5. A.A. Balkema Publishers, Rotterdam, The Netherlands.

O'Dell TE, Ammirati JF, Schreiner EG, 1999. Species richness and abundance of ectomycorrhizal basidiomycetes carpophores on a moisture gradient in the Tsuga heterophylla zone. Canadian Journal of Botany 77: 1699-1711.

Pegler DN, Laessoe T, Sponner BM, 1995. British Puffballs Earthstars and Stinkhorns. Royal Botanic Gardens, Kew.

Pegler DN, Roberts PJ, Sponner BM, 1997. Chanterelles and Tooth Fungi: an Account of the British Cantharelloid and Stipitate hydnoid fungi. Royal Botanic Gardens, Kew.

Richard F, Moreau P-A, Selosse M-A, Gardes M, 2004. Diversity and fruiting patterns of ectomycorrhizal and saprobic fungi in an old-growth Mediterranean forest dominated by Quercus ilex L. Canadian Journal of Botany 82: 1711-1729.

Richard F, Millot S, Gardes M, Selosse M-A, 2005. Diversity and specificity of ectomycorrhizal fungi retrieved from an oldgrowth Mediterranean forest dominated by Quercus ilex. New Phytologist 166: 1011-1023.

Salerni E, Laganà A, Perini C, Loppi S, De Dominicis V, 2002. Effects of temperature and rainfall on fruiting of macrofungi in oak forest of the Mediterranean area. Israel Journal of Plant Sciences 50: 189-198.

Senn-Irlet B, Bieri G, 1999. Carpophore succession of soilinhabiting macrofungi in an autochthonous subalpine Norway spruce forest of Switzerland. Forest Ecology and Management 124: 169-175.

Smith JE, Molina RJ, Huso MMP, Luoma DL, McKay D, Castellano MA, Lebel T, Valachovic Y, 2002. Species richness, abundance, and composition of hypogeous and epigeous ectomycorrhizal fungal carpophores in young, rotation-age, and old-growth stands of Douglas-fir (Pseudotsuga menziesii) in the Cascade Range of Oregon, U.S.A. Canadian Journal of Botany 80: 186-204.

Smith ME, Douhan GW, RizzoDM, 2007. Ectomycorrhizal community structure in a xeric Quercus woodland based on rDNA sequence analysis of carpophores and pooled roots. New Phytologist 174: 847-863.

Vogt KA, Bloomfield J, Ammirati SR, 1992. Carpophore production by basidiomycetes, with emphasis on forest ecosystems. In: Carrol, G.C., Wicklow, D.T. (Eds), The Fungal Community: its Organization and Role in the Ecosystem. Marcel Dekker, New York, USA, pp. 563-581.

Watling R, 1995. Assessment of fungal diversity: macromycetes, the problems. Canadian Journal of Botany 73: S15-S24. 